\title{
BUILDING SUSTAINABILITY IN SPORT: A CLEAR OFFSIDE OR CHANCE FOR A "SLOW" REBIRTH?
}

Training, selection, peaking, workloads are common notions associated with our society. However, these concepts are also inherent in sport as well, where 'the winner takes all'. Thus the logic of modern sport resembles the capitalist milieu in which it has evolved: individualism, competitiveness, peak performance, and productivity are all essential components. Modern sport is also often depicted as being a remedy to society's ills, making sport a linchpin of the population's well-being: empowering control over health, educating people to reach their goals or serving as a good example for future generations. But there is a danger that modern sport is primarily becoming a tool for generating profit.

The aim of this paper is to formally examine how sport is related to the principles of sustainability, and its potential impact on well-being. Although several project aims to safeguard three dimensions of sustainability: environmental, social and economic values, drawing on a growing body of scholarships on sustainability best and worst practice, this article discusses the environmental, social and economic consequences of sport activities, using the aspect of society and insights from sport mega-events.

Keywords: economic, environmental, legacy, public value, social, sport, sustainability, well-being

$S^{\text {pot }}$ port and sustainability. Easily used, although hardly evident concepts. Searching in Google Scholar the first returns 196.000, the latter 172.000 in the titles of the articles. However, only 111 articles are having both at once. Why does this happen? What consequences can we draw from it? Are the disciplines in an early stage of research and thus having fewer articles? Marrying the two concepts having nothing common? Or those studies are existing, only the two keywords are missing from the title? I believe none of the above explanations are irreprehensible.

Sustainability became such ,vogue word" like strategy or globalization. Utilizing it in articles or at presentations for the sake of having it seems indispensable. Asking for an accurate definition could put one in trouble. Researchers tend to struggle with the issue as well.

The situation regarding sport is rather different. Although a favorite topic, its research accelerated in social sciences only in the last decades. Moreover in the last years the extent of the development and alteration of the field was enormous. On the other hand, the entertainment connected with the sport makes it hard to relate the notion to the sciences. Furthermore, - as detailed later - its conceptualization still stands on fugacious grounding.

In this paper I describe the types of sport then the pillars of sustainability. From society's viewpoint I explore the connections, draw the shared segments and answer the question: how do those two concepts coherent in researches?

\section{Sport}

An important, not economic element touched in the definition of the sport: the sport, the exercise is a cultural universal. An activity, which stands as an element of religious rites, play or entertainment being an organic part of human cultures. To the extent the sport, exercise depends on the specific society, to its culture, that would prevent estrangement, socializing as a tool to promote integration of individual values, so can react to the society. Sport, as a social subsystem has its internal laws. The nature of the operation, the change in the purpose, always affected by the historical, social, political or economic change of the environment (Földesiné - Gál - Dóczi, 2010).

One of the most comprehensive definitions made by Nagy, who considers sports are based on historical experiences and standards, playing a form of activity, that separated from direct production processes, competitive type, emotional, which are both suitable for excitement creation and reduction (Nagy, 1995).

The Oxford Dictionary (2017) defines it as: „An activity involving physical exertion and skill in which an individual or team competes against another or others for entertainment."

While official sport definition: "Sport means all forms of physical activity which, through casual or organized participation, aim at expressing or improving physical fitness and mental well-being, forming social relationships or obtaining results in competition at all levels" (European Sports Charter, 1997).

From a research point of view, it was imperative that the narrow-broad framework to further break down, and ask the question: "what is the subject of exchange here?" Along with this issue Dénes, Misovitz (1994) and Nagy (1995) sharply separated professional sport (where entertainment, the others movement became the subject of exchange) from the recreational sport. An enormous range of synonyms (professional, elite, high-performance) used to show the main differences, as it is the former, where the athletes get paid and pursue it as a profession. The latter is done in recreational time, for the sake of exercise, or health prevention. From consumer point of view, we can identify an active-passive boundary, but the separation can 
not be so sharp. There are amateur athletes, who exchange entertainment (see Andorra national football team), and vice versa, there are some professionally paid ones whose product has hardly been consummated.

Although they are professionals, by their actions rather than creating pure profit via views - they create something else, less tangible, which leads somewhat towards sustainability.

In its examination of the leisure sport and professional sport, Henderson (2009) and Pitts (2002) pointed out a significant disproportion. In the editions of the last twenty years of Sport Management Review and the Sport Marketing Quarterly, approximately five times more articles dealt with the professional sport, than recreational relatives.

Although I think, that the definition and the separation are far from perfect, the two sections can be clearly confinable and well analyzable. The classic sport definition includes professionals who compete in a physical activity is in the center of the Figure1

Figure 1.

Activities regarded sport as per definition (based on András, 2002)

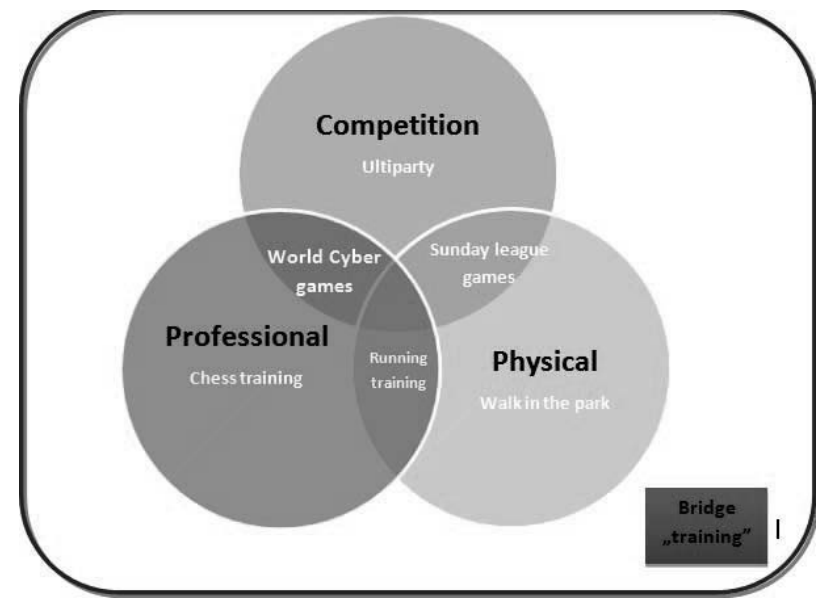

\section{Sustainability}

Although the word: sustainability has been used only for a few decades, its content can be discovered already back in the 18th century at Malthus (1798). Malthus thought that if the human population continued to grow, food production would not be able to keep up with demand, so was arguing that the human population was at risk of outgrowing its carrying capacity. In 1864, the English economist William Stanley Jevons observed that technological improvements that increased the efficiency of coal-use led to the growing consumption of coal in a wide range of industries. He argued that, contrary to common intuition, technological progress could not be relied upon to reduce fuel consumption (Jevons, 1864).

The modern sense of term: "sustainable" was first mentioned by Brown R. Lester (1981). Sustainable development theory begins to spread in the '80's when The Brundtland Commission officially released Our Common
Future, also known as the Brundtland Report. Two markedly different trends also emerged concerning the nature and perception of the economy. Ecological Economics and Environmental Economics approach differ in the following: while the former does not necessarily hold the economic growth a sustainable process, the latter does not call into question the sustainability of economic growth (Kocsis, 1999; Bajmóczy-Málovics, 2009) .

Environmental sustainability, however, is often defined in two different ways. The so-called weak sustainability signifies the underlying concept that natural and human-made capitals can be substituted with each other and the level of consumption can be maintained as long as a possibly decreasing level of natural capital is compensated for by the increase in human-made and human capital. In contrast, strong sustainability does not allow for such a perfect substitution and insists that the stock of natural capital should remain constant to ensure that future generations have the possibility to enjoy the flows that nature provides (Jackson, 2010).

Several researchers have made attempts to summarize the content of the expression (Daly, 1991; Pearce - Atkinson, 1995; Kerekes, 2007), the concept of the Brundtland report remained the most referred to:

\section{"Sustainable development is development that meets the needs of the present without compromi- sing the ability of future generations to meet their own needs" (Our Common Future, 1987, p. 27.).}

That is, do not jeopardize the well-being of children and grandchildren, applies not only the natural environment. Two important definitions arise: resource constraints and the need related the poverty, the natural environment and the issue of social equality. But the phrase raises several questions. First of all, do the emerging needs have to be met? Second, how do we know in a specific moment what will be a legitimate need for the future generation? In any case, Littig and Giessler (2005) emphasized the need to change human lifestyles in order to preserve the ecological system and the sustainability of resources.

Figure 2.

The three-pillar sustainability (source: http:// onecommunityranch.org/ecological-sustainable-designtool-the-sustainable-development-matrix-ethosolution/)

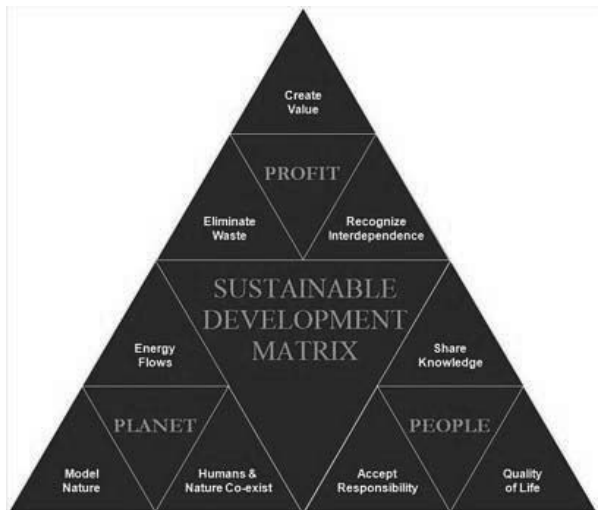


So the definition of sustainability has enlarged to three pillars where in addition to the environmental aspect, the economic and social pillar has an equally important role. (Figure 2., cf. Kocsis, 2013)

With this enlargement, however the interpretation of a wide range of options has been opened. According to Jones, Selby \& Sterling (2010) the conditions for both humankind and environment of mutual prosperity, security and the chance of survival can co-exist and have to be met. Much more generally, Senge (2008) suggested to consider every boundary, which will contribute to a healthy community of the future. McMichael, Butler \& Folke (2003) concluded to maximize the chances for the environment, and the social conditions enable to help reaching of safety, well-being, and health. Ehrenfeld (1978), formerly widened those with biodiversity, human rights, equality, openness, and respect dimensions.

While analysing the several aspects of the sustainability White (2013) checked - with the establishment of wordcloud - the phrases that appear in different sustainability definitions. As a result, the most common "social," "environment," and "economic" words were closely followed by the "human," "resource" and "development" phrases. But the "community," "next generation" and "needs" words were also common. Surprisingly, the "well-being" was omitted.

In another experiment Vallance, Perkins \& Dixon (2011) sorted the different trends and created a three-dimensional model, in which the "development sustainability," "bridge sustainability" and the "maintenance sustainability" established. The first addressing basic needs, the creation of social capital, justice and so on; "bridge sustainability" concerning changes in behavior so as to achieve biophysical environmental goals. While "maintenance sustainability" referring to the preservation - or what can be sustained - of sociocultural characteristics in the face of change, and the ways in which people actively embrace or resist those changes.

Table 1.

Linking Professional Sport and Sustainability

\begin{tabular}{|c|c|c|c|}
\hline & \multicolumn{3}{|c|}{ ANALYSIS SCALE } \\
\hline $\begin{array}{l}\text { EXAMINATION } \\
\text { SCOPE }\end{array}$ & $\begin{array}{c}\text { Micro } \\
\text { (Individual) }\end{array}$ & $\begin{array}{c}\text { Mezo } \\
\text { (Company.League) }\end{array}$ & $\begin{array}{c}\text { Macro } \\
\text { (Mepa-event.State) }\end{array}$ \\
\hline \multirow{2}{*}{ Sustainability } & $\begin{array}{l}\text { - Consumer habit } \\
\text {-Health protection } \\
\text {-Environmental awareness } \\
\text {-Empowerment } \\
\text {-Self-esteem and life skills }\end{array}$ & $\begin{array}{l}\text {-Emvlovment } \\
\text {-Community-wide } \\
\text { participation } \\
\text {-Competitiveness } \\
\text {-Capital investments } \\
\text {-Environmental } \\
\text { management }\end{array}$ & $\begin{array}{l}\text {-Social equality } \\
\text {-State investment } \\
\text {-Community cohesion } \\
\text {-Human capital } \\
\text {-Social capital } \\
\text {-Event policies }\end{array}$ \\
\hline & \multicolumn{3}{|c|}{$\begin{array}{l}\text {-Carbon footprint } \\
\text {-Energyg consumption } \\
\text {-Water usage } \\
\text {-Well-being }\end{array}$} \\
\hline
\end{tabular}

The concept of sustainable development at the 2005 World Summit and by the 2006 UN High-Level Panel on System-Wide Coherence, revealing that world leaders at the Summit segregated the three pillars of sustainable development, while the Panel attempted to apply sustainable development as a cross-cutting issue.
In the Table 1. I show the analysis scales and examination scopes linking sustainability and professional sport. My aim is to analyse the environmental, social and economic sustainability of professional sport activities, using the aspect of society and insights from sport mega-events.

\section{Keeping the field green: environmental sustainability became winning strategy in professional sport}

Sport have been deemed to be a special business, because of the need to attain two different objectives together, namely, success on the field and success in business performance. To achieve these goals, sport institutions must organize their resources and adapt their financial structure to be able to attain acceptable efficiency levels as well as an adequate sustainable growth. The required balance in dual value creation can also be shifted: research from Stocker, (2012) shows that the sporting success is far more important in the professional Hungarian sport businesses than the economic success, and the market is not valuing the sporting success in tangible terms to the amounts of its creation costs. Findings indicate that the teams that operate close to the sustainable growth ratio become more efficient on the field than those where the differences are greater (Guzman, 2010).

The high interest generated by sports mega-events (Olympic Games, football World Cups, European Championships) means millions of people try to be on the spot. Consumption, travel, and moving of goods are concentrated in a small area for a short time. This means a trade-off challenge and leads to a significant environmental impact. Events potentially impact upon local ecosystems; utilize reserves of exhaustible natural capital, and contribute to carbon emissions related to climate change. Furthermore, in the context of environmental challenges, the question has been asked: what is the appropriate level of environmental impact, legacy one generation of a sport should make on the next generation (Mallen - Adams - Stevens - Thompson, 2010)? According to Schmidt (2006, p. 287.), the discussion on the environmental impact of sports, whether played or watched, has two objectives:

- to reduce the ecological footprint of sports activities,

- to exploit the popularity of sports to raise environmental awareness in general.

The event-focused approach (Cantelon - Letters, 2000; Jones, 2008) drew attention to the local eco-systems, the irreplaceable environmental capital, and climate change.

Benefits of organizing a major sporting event can have: infrastructure development, sports facilities, improving competitiveness, employment increasement, etc. Concerning the biggest sport event in the world, the Olympics, the impact of economic aspects gradually shifting the balance towards other inputs. From the Games in Lillehammer in 1994 through to Sydney 2000, and more recently in Torino in 2006, and London 2012 the environment has increasingly become a core and a winning competitor in the 
process of selecting the host of the Olympic Games. So, the International Olympic Committee (IOC) has "recognized the importance of Environmental Sustainability by adding a paragraph to the Olympic Charter that positioned the environment as the third pillar of Olympism (alongside the first two components of sport and culture)" (Paquette et al., 2011, p. 356.).

Gratifyingly starting with Lillehammer Winter Olympics the organizers of the 1994 Winter Olympic Games in Lillehammer developed a comprehensive environmental action plan, and the 2000 Summer Olympic Games in Sydney took steps towards staging the first 'green games.' More recently, organizers of the 2006 World Cup Football competition in Germany introduced Green Goal ${ }^{\mathrm{TM}}$. The first environmental initiative at a FIFA World Cup set environmental protection targets, working to reduce resource use regarding water, refuse, energy and transport, and with plans to offset the 100.000 tons of carbon emissions. Indeed, London 2012 included as part of its winning Olympic bid a commitment to measure and take steps to minimize the environmental impacts of the forthcoming Games. The London Olympics also served as demonstration purposes: excellent eco-rated Olympic village, hydrogen fuel cell vehicles operating in an eco-driving initiative way (London 2012, 2005b). With the environment playing a key role in the concept became a winning scenario (Steiner, 2006).

Organizing Committees of the Olympics face issues regarding what should the future of the event be, i.e. questions at the 'hyper-strategic level.' There are then a series of 'more-strategic' questions perhaps concerning how far existing waves of sporting activity can be made more sustainable, or more operational problems regarding the placement of events, or how far mitigation of negative externalities can be achieved by policy changes (Morrison-Saunders - Therival, 2006).

Measurement of environment targets become more and more significant issue. Collins, Jones \& Munday (2009) used two methods, ecological footprint, and environmental input-output model to provide valuable information for event organizers and policy-makers on factors influencing the scale of an incident' environmental impact, and the types of strategies needed to reduce the effect of visitor travel. One of the first measurement of major sports events was made by Collins, Flynn, Munday \& Roberts (2007) in Great Britain. The Ecological Footprint results show how, within a short space of time, a large environmental impact can be produced by visitors attending major events such as the FA Cup Final. The number of visitors, how they travel to an event, the types of food and drink they consume and the wastes they produce can generate significant ecological impacts.

In addition to sports events and tourism, there is a serious list of examination on facilities. The focus is on developing sports facilities (stadiums, halls, courts) to the most environmentally efficient way, decreasing the use of natural resources. This, in turn, leads from professional sport to recreational, since there are similarities. Same facilities can be utilized by both professional and amateur athletes, and there are several ways of leisure activities, like City Marathons visited by thousands is a short time. So similar environmental challenges occur as a major competitive sports event. Many feel the greatest challenge is the environmental education, changing environmental attitude. Successful and respected athletes can be a role model and initiate this.

\section{More than legacy: economic sustainability in sport mega-events}

Nowadays the corporate sustainability is closely related to corporate social responsibility (CSR), and today the area is completely "in sync," or overlapped. To put it another way, both CSR and sustainability understand that the context, community, and environment in which a business operates is integral to that business' success. Sustainability, then, goes on step further by taking into account the needs of the future generations (Montiel, 2008). Also, in the field of sports economy stakeholders motivated in long term planning, smart growth, and cost reductions along. In professional sport decision makers soon found essential to keep the spectacle, excitement and unpredictability imbalances in financial resources and conditions in the short term should be avoided.

Consideration is now being given to the unique context in which sport operates, and some authors argue that nature and the role sustainability plays in a sport organization may be different than in other industries (Babiak - Wolfe, 2007). For instance, Smith \& Westerbeek (2007) claimed that sport, broadly defined, has some unique factors that may positively affect the nature and scope of sustainability efforts including mass media distribution and communication power, youth appeal, positive health impacts/association, social interaction, and sustainability awareness.

The concept of legacy regarding sport mega-events closely connected with sustainability, however, has appeared to gain enormous traction and become an important part of the "triple bottom-line" evaluation processes, where city-states seek to broaden the inputs for an event's evaluation beyond economic impact (Carlsen - Soutar, 2000). As Cashman (2005) notes, legacy has been viewed predominantly in a positive light where, . . . the term is used by organizing committees, it is assumed to be entirely positive, there being no such thing as negative legacy when used in this context. (Secondly,) it is usually believed that legacy benefits flow to a community at the end of the Games as a matter of course (p. 15.). The results of the 2002 conference was the identification of six tangible and intangible legacies to hosting Olympic Games; economic impact, cultural considerations, social debate, sporting legacy, political legacy, and the value of Olympic education.

Sport franchises are no different from other companies in their intent to earn a profit and positively impact the economy in the cities in which they operate. Although sport teams are not major employers, they can have a considerable economic impact on a city, evidenced primarily 
in the spending generated by fans (Blair, 1997). Unlike traditional businesses, however, sport franchises are valued on their revenues, rather than cash flow and assets. Since professional sport teams hold a high profile in the communities where they are based, this category is perhaps more important to sport teams because, to succeed financially, each team is dependent on the local community to purchase tickets and other team goods (Extejt, 2004). It appears that teams across leagues all engage in similar CSR, legacy and sustainability activities and practices with a primary focus on youth, education, health, and community. As some of these areas are beyond the "core competencies" of sport teams and leagues, a relevant dimension to explore would be the institutionalization of these practices in sport.

The sport's success is beneficial in social terms, whereas the local community have a sense of pride and cohesion. The financial sustainability of the sport success also, - due to the expanding commercial opportunities through the operation of the organization - can be placed on the business basis, and to be independent of the current support policy. They refer to a path of socio-economic development that would be financially balanced, socially equitable, ethically responsible and adequately integrated into the long-term ecological balance of the natural environment. Sustainable development is also a dynamic process that continues to evolve and grow as lessons are learned and ideas re-examined (Furrer, 2002). American sports have "draft-system" and the application of the salary cap to help the case. In Europe, the latest initiative in football is the financial fair-play, which applied to lead professional clubs to exploit the administrative incentives, predictable, long-term financial planning.

Regarding recreational sport it has been much harder to rise on similar initiative. Szabó (2012) analyzed the operation of recreational sport, focusing on markets, value creation and operational level. Emphasizing that from sporting investment there is a priority to equality and environmental sustainability investments.

\section{Value for the public: social sustainability impact on sport}

Public value describes the value that an organization contributes to society. In contrast to other management concepts, public value systematically takes a societal viewpoint, since it presumes that individuals develop and grow depending on the society they live in. It is definitely not fully captured in an annual report or financial statement. Public value is a unique concept to explicitly analyze how an organization contributes to the quality of relationships between an individual and what is called "society", i.e. collectively shared values, which constitute social relations and help integrate individuals in a social system. Whereas the notion of corporate social responsibility takes primarily moral-ethical considerations into account, public value and social sustainability broadens the perspective to a number of other collectively shared values.
The quality of life, education, justice, the development of communities is seen as the essential elements of social sustainability and human well-being. These are values that important for now and future generations. Surprisingly, though little research has so far been tried to build the concept of social sustainability around the sport. They investigate much more of a leisure sport, sporting activities and peace, or sports, cultural differences and the relationship between tolerance (Barker et al., 2011; Dagkas - Benn - Jawad, 2011).

Lawson (2005) was one of the few to discovered that athletes can demonstrate how competitiveness and hard work can co-exist alongside honesty, fairness, solidarity, compassion, empathy and grace, moving in the direction of sustainability. In most general texts on sustainable development, the social needs of present and future generations are discussed regarding equity, ethics, and rights. Equity is regarded as denoting fairness - social justice and equal access to opportunities - generate a range of positive social effects including: reinforcing collective identities; uniting people; improving self-esteem; increasing civic pride; raising awareness of disability; inspiring children; providing experience of work; encouraging volunteering, increasing participation in sport; and promoting well-being/healthy living (Smith, 2009). But where competition exists, there should be winners and losers. If we consider increasing capabilities to carry out valuable activities to human well-being important, the development and the quality of life not only depends on the achieved performances but also on what options are available to the one in that society (Pataki, 1998). From sport and social sustainability point of view, health became the central topic, around most of the researches made. The United Nations Development Program (UNDP) reports: „People are the real wealth of a nation. The real objective of development should be to create an enabling environment for people to enjoy long, healthy and creative lives" (Human Development Report, 2010, p. 24.).

Taking into consideration that according to Nefiodow the carrier of a new long economic cycle will be health in a holistic sense - including its physical, psychological, mental, social, ecological and spiritual aspects - the fundamental innovations of the sixth Kondratieff-waves are "psychosocial health" and "biotechnology" (Nefiodow Nefiodow - Simone, 2014). But how can sport help health both physical and psychological? Lawson (2005) found that sport should not see as a homogenous entity. Rather as two underlying philosophy (high performance and recreational sport) which are radically different from each other. Therefore sees the relevance of sustainability is slight about the professional sport in which your keywords are the training, selection, peak performance and load, while fully compatible with the values of recreational sport, often identified with cooperation, participation, relish, and delight. Recreational sport can create a social network, develop community identity, improve human health, can have a real effect on the well-being and human capital.

Despite its importance, social needs are recognized as the least explored element of Brundtland's widely accepted definition of sustainable development (Smith, 2009). 
Social impact can be defined as the manner in which events "affect changes in the collective and individual value systems, behavior patterns, community structures, lifestyle and quality of life" (Balduck - Maes - Buelens, 2011, p. 94.). The above definition shows how the understanding of social elements is involved. That is why several concepts tried to separate the individual, community, organizational and institutional sustainability while talking about sport. From the institutional point of view Szabó (2011) wrote, that sport can catalyze the dialogue between different cultures and help overcome the various forms of discrimination. Chalip (2006) and Oakley - Rhys (2008) emphasized the sport society building role, the social cohesion, and strengthening the community spirit. Loland (2006) stressed that in individual standpoint, we might consider how ones within performance sports can flourish. The continuous quest for new records is built on the impossible quest for unlimited growth in limited systems.

From this perspective, the question arises as to how the sport itself, affect the relationship between people and the environment? The anthropocentric standpoint is that the professional sport can be pursued in such a way that build mutual respect and care about prosperity. The previous researches also made attention on the psychological aspects. Coakley (1992) examined one of the leading health-related issue, the burn-out. Cases of burnout suggest that the roots are grounded in the social organization of high-performance sport. Recommendations for preventing burnout call for changes in the social organization of high-performance sport, changes in the way sport experiences are integrated into the lives of young athletes, and modifications in the structure and dynamics of relationships between athletes and their significant others. Although it is well-established that the ability to manage stress is a prerequisite of sporting excellence, the construct of psychological resilience has yet to be systematically examined in athletic performers (Fletcher - Sarkar, 2012).

The importance of individual well-being through athlete's career explored by Lundqvist (2011). He established definitions of well-being, the purpose of the study was to investigate factors characterizing and signifying well-being and psychosocial factors on both a global and a contextual level. Social well-being included seeing others' positive characteristics, rejoicing in others' successes, offering consolation in adversity, and providing unconditional support regardless of performance.

The difficulties associated with the closure of the professional career, employment and the relationship between human capital and Ling \& Hong (2014) encountered by athletes in the course of their sports careers. Human capital refers to the summation of knowledge, skill, health, information and so on that is used to increase the future effectiveness or realize the value multiplication that is gained by the investment activity. The issues relating to human capital have grave consequences for the re-employment of the retired elite athletes, including a lack of education and qualifications, poor health caused by illness and injury related to sports, and narrow skill sets brought about by specific training.
It came to the conclusion that in the professional sport problems detection is in the foreground rather than solving. This seems to be the least sustainable from the six sub-systems. After all, if you're talking about a system where internal stakeholders (athletes) are trying to generate values to convey the outsiders (society) while forced short interest-follow (during a short career earning prosperity for the whole life, overloaded, or by using the doping). And because the system is lacking long-term thinking, the accumulated human capital remains unused, no career model, and there are rarely respected coaches, who care the future generations. In the absurd nature of the system, athletes - quoted the examples of the youngs would not do it again and take the same burden.

\section{Conclusion}

My aim was to show how the two concepts (sustainability and sport) are coherent to each other. I examined it leading through three pillars of sustainability. The results show that sustainability more and more became an important factor in the field of sport. From mega-sports events strategies to individual recreational activities, elements of sustainability can be found. The problems regarding for instance with social sustainability is still mounting, as athletes often seen as peak performance generating thing, equal to a money making tool. Hence athletes get over the peak of its physical performance, they are simply "thrown away". That is one of the several reasons why sustainability should be meticulously managed through the three-pillars, not over-emphasizing one, because for example it will be in vain sports club or a sports enterprise became in economic terms sustainable through reaching long-term financial targets, while operating a system which exploits the human capital. Pillars of sustainability should be explored in linked unit, rather than decomposed, as some point in this study I followed.

Finally, let me end with actual words of Elemer Hankiss (1983, p. 248.): "Because, if a value permanently combats with manufacturing issues, sooner or later, the erosion of its social value starts. While losing their credentials, enticement weakens, it stops being able to control of the human consciousness and behavior; but it could be able to plaything the formal ritual by becoming an obstacle to the emergence of a new, functional values. This is the Foundation of renewal. "

\section{References}

András K. (2002): Üzleti elemek a sportban. Doktori $(\mathrm{PhD})$ értekezés tervezet. Budapest: BKÁE

Babiak, K. - Wolfe, R. (2007): CSR and Professional Sport: A Perfect Fit? Paper Presented at the Meeting of the North American Society for Sport Management, Fort Lauderdale, FL.

Bajmócy Z. - Málovics Gy. (2009): A fenntarthatóság közgazdaságtani értelmezései. Közgazdasági Szemle, LVI (5), p. 464-483.

Balduck, A. - Maes, M. - Buelens, M. (2011): The social impact of the Tour de France: Comparisons of resi- 
dents' pre- and post-event perceptions. European Sport Management Quarterly, 11(2), p. 91-113.

Barker, D. M. - Barker-Ruchti, N. - Gerber, M. - Gerlach, E. - Sattler, S. - Pühse, U. (2011): Youths with migration backgrounds and their experiences of physical education: An examination of three cases. Sport, Education and Society, p. 1-18.

Blair, J. P. (1997): Sport-Based Economic Development. Economic Development Review, 15(2), p. 51-55.

Carlsen, J. - Soutar, G. (2000): Event evaluation research. Event Management, 6(4), p. 247-257.

Cashman, R. (2006): The Bitter-Sweet Awakening: The Legacy of the Sydney 2000 Olympic Games. Petersham: Walla Walla Press

Chalip, L. (2006): Toward a distinctive sport management discipline. Journal of Sport Management, 20(1), p. 1-21.

Coakley, J. (1992): Burnout Among Adolescent Athletes: A Personal Failure or Social Problem? Sociology of Sport Journal, 1992, 9, p. 271-285.

Collins, A. - Flynn, A. - Munday, M. - Roberts, A. (2007): Assessing the environmental consequences of major sporting events: the 2003-04 FA Cup Final. Urban Studies, 44, p. 457-476.

Collins, A. - Jones, C. - Munday, M. (2009): Assessing the environmental impacts of mega sporting events: Two options? Tourism Management, 30, p. 828-837.

Dagkas, S. - Benn, T. - Jawad, H. (2011): Multiple voices: Improving participation of Muslim girls in physical education and school sport. Sport, Education and Society, 16(2), p. 223-239.

Daly, H. E. (1991): Elements of Environmental Macroeconomics. In: Costanza, R. (ed.): Ecological Economics. New York: University Press, p. 32-46.

Dénes F. -Misovicz T. (1994): Bevezetés a sportökonómiába. Vezetéstudomány, 25(3), p. 57-61.

Ehrenfeld, D. (1978): The Arrogance of Humanism. New York: Oxford University Press

European Sports Charter (1992): Article 2, adopted by the Committee of Ministers on 24 September 1992 at the 480th meeting of the Ministers' Deputies

Extejt, M. M. (2004): Philanthropy and Professional Sport Teams. International Journal of Sport Management, 5(3), p. 215-228.

Fletcher, D. - Sarkar, M. (2012): A grounded theory of psychological resilience in Olympic champions. Psychology of Sport and Exercise, 13 (2012), p. 669678.

Földesiné Szabó Gy. - Gál A. - Dóczi T. (2010): Sportszociológia. Budapest: Semmelweis Egyetem Testnevelési és Sporttudományi Kar, p. 11-20, 43-70.

Furrer, P. (2002): Sustainable Olympic Games. A dream or a reality? unpublished manuscript, $<$ http://www. omero.unito.it/web/Furrer\%20(eng.).PDF>.

Guzmán, I. (2006): Measuring efficiency and sustainable growth in Spanish football teams. European Sport Managements Quarterly (ESMQ), vol. 6 (3), p. 267287.

Hankiss E. (1983): Társadalmi csapdák. Diagnózisok. Budapest: Magvető Kiadó
Henderson, K. A. (2009): A paradox of sport management and phisical activity interventions. Sport Management Review, 12(2), p. 57-65.

Human Development Report (2010): 20th Anniversary Edition, The Real Wealth of Nations: Pathways to $\mathrm{Hu}-$ man Development, Published for the United Nations Development Programme (UNDP)

Jackson, T. (2010): Prosperity without Growth? The Transition to a Sustainable Economy. London: UK Sustainable Development Commission

Jevons, W. S. (1864): The Coal Question: an Enquiry Concerning the Progress of the Nation, and the Probable Exhaustion of our Coal Mines. London: Macmillan

Jones, P. - Selby, D. - Sterling, S. (2010): More than the sum of their parts? Interdisciplinarity and sustainability. In: Jones, P. - Selby, D. - Sterling, S. (eds.): Sustainability education: Perspectives and practice across higher education. London: Earthscan, p. 17-38.

Kerekes S. (2007): A környezetgazdaságtan alapjai. Budapest: Aula Kiadó

Kocsis T. (1999): A jövő közgazdaságtana? Az ökológiai közgazdaságtan múltja, jelene és jövője az uralkodó neoklasszikus nézetek tükrében. Kovász III. évfolyam, 3. szám 1999. ősz, p. 131-164.

Kocsis T. (2013): Looking through the dataquadrate: characterizing the human-environment relationship through economic, hedonic, ecological and demographic measures. Journal of Cleaner Production, 35, p. 1-15.

Lawson, H. (2005): Empowering people, facilitating community development, and contributing to sustainable development: The social work of sport, exercise, and physical education programs. Sport, Education and Society, 10(1), p. 135-160.

Lester, B. R. (1981): Building a sustainable sosienty. A Worldwatch Institute Book. New York: W.W. Norton

Ling, Z. - Hong, F. (2014): After the Glory: Elite Athletes' Re- Employment in China. The International Journal of the History of Sport, Vol. 31, No. 6, p. 635-651.

Littig, B. - Grießler, E. (2005): Social sustainability: a catchword between political pragmatism and social theory. International Journal of Sustainable Development, Vol. 8, Nos.1/2

Loland, S. (2006): Olympic sport and the ideal of sustainable development. Journal of the Philosophy of Sport, 33(2), p. 144-156.

London 2012 (2005b): London 2012 candidate file: Theme 5 - Environment and meteorology. London 2012. Available from. www.london2012.org.

Lundqvist, C. (2011): Well-being in competitive sports The feel-good factor? A review of conceptual considerations of well-being. International Review of Sport and Exercise Psychology, Vol. 4, No. 2, September, p. 109-127.

Malthus, T. R. (1976): An Essay on the Principle of Population. New York: Norton (Originally published in 1798.)

McMichael, A. J. - Butler, C. D. - Folke, C. (2003): New visions for addressing sustainability. Science, 302, p. 1919-1920. 
Montiel, I. (2009): Corporate Social Responsibility and Corporate Sustainability: Separate Pasts, Common Futures. Organization \& Environment, 21(3), p. 245269.

Morrison-Saunders, A. - Therivel, R. (2006): Sustainability integration and assessment. Journal of Environmental Assessment Policy and Management, 8(3), p. 281-298.

Nagy P. (1995): Bevezetés a professzionális sport közgazdaságtanába. In: Új utak a közgazdasági, üzleti és társadalomtudományi képzésben. BKE Jubileumi Konferencia 1995, Budapest, I. kötet, p. 488-493.

Nefiodow, L. - Nefiodow, S. (2014): The Sixth Kondratieff. A New Long Wave in the Global Economy. Charleston: Createspace

Oakley, B. - Rhys, M. (2008): The Sport and Fitness Sector. New York: Routledge

Oxford dictionaries (2017): Oxford: Oxford University Press

Pataki Gy. (1998): A fejlődés gazdaságtana és etikája Tiszteletadás Amartya Sen munkásságának. Kovász, II. évfolyam, 4. szám - 1998. Tél, p. 6-17.

Pearce, D. - Atkinson, G. (1995): Measuring Sustainable Development. In: Bromley, D. (ed.): The Handbook of Environmental Economics. Oxford: Blackwell

Paquette, J. - Stevens, J. - Mallen, C. (2011): The interpretation of environmental sustainability by the International Olympic Committee and Organizing Committees of the Olympic Games from 1994 to 2008. Sport in Society, 14(3), p. 355-369.

Pitts, G. B. (2002): Examining Sport Management Scholarship: An Historical Review of Sport Marketing Quarterly. Sport Marketing Quarterly, 11(2), p. 84-92.

Schmidt, D. W. (2006): Putting the earth in play: environment awareness and sports. Environmental Health Perspectives, 140 (5), A286-A295.
Senge, $P$. (2008): Working together for a future that has a future. Association for the advancement of sustainability in higher education (video). Retrieved from http:// www2.aashe.org/conf2008/video_senge.php

Smith, A. (2009): Theorising the Relationship between Major Sport Events and Social Sustainability. Journal of Sport \& Tourism, 14:2-3, p. 109-120.

Smith, A. C. T. - Westerbeek, H. M. (2007): Sport as a Vehicle for Deploying Corporate Social Responsibility. The Journal of Corporate Citizenship, 25(Spring), p. 43-54.

Steiner, A. (2006): Quoted in London 2012's One Planet Olympics policy approval. United Nations Environmental Programme, News Centre. Available from http://www.unep.org/Documents.Multilingual/Default.asp? DocumentIDL'483\&ArticleIDL'5314\&1L'en.

Stocker, M. (2012): Value Creation of Knowledge-intensive companies. Corvinus Doctoral School in Business Administration. Budapest: Budapesti Corvinus Egyetem

Szabó Á. (2012): A magyar szabadidősport müködésének vizsgálata. PhD-értekezés. Budapest: Budapesti Corvinus Egyetem

Szabó Á. (2011): Milyen értéket teremt a szabadidősport, és mi a kapcsolata a versenyképességgel? Vezetéstudomány, XLII. ÉVF. 2011. KÜLÖNSZÁM/ISSN 01330179

Vallance, S. - Perkins, C. H. - Dixon, E. J. (2011): What is social sustainability? A clarification of concepts. Geoforum, Volume 42, Issue 3, June 2011, p. 342-348.

White, M. A. (2013): Sustainability: I know it when I see it. Ecological Economics, 86, p. 213-217.

World Commission on Environment and Development (1987): Our Common Future. Oxford: Oxford University Press 